\title{
Different forms of ghrelin exhibit distinct biological roles in tilapia
}

\author{
Larry G. Riley* \\ Department of Biology, California State University Fresno, Fresno, CA, USA
}

\section{Edited by:}

Hiroyuki Kaiya, National Cerebral and

Cardiovascular Center Research

Institute, Japan

Reviewed by:

Kouhei Matsuda, University of

Toyama, Japan

Yoshihiro Nishi, Kurume University,

Japan

*Correspondence:

Larry G. Riley, Department of Biology,

California State University Fresno,

2555 East San Ramon, Fresno, CA

93740, USA

e-mail: Iriley@csufresno.edu
Ghrelin has been identified in all vertebrate classes, including sharks. Each species possesses multiple forms of ghrelin that vary in peptide length and acyl modifications (e.g., $n$-hexanoic, $n$-non-anoic, n-octanoic, and $n$-decanoic acids) including des-acyl ghrelin. Octanoylated ghrelin has been shown to be a potent $\mathrm{GH}$ secretagogue, orexigenic factor, and plays a role in overall metabolism in vertebrates. In the tilapia model, octanoylated ghrelin (ghrelin-C8) and decanoylated ghrelin (ghrelin-C10) exhibit different biological actions. This mini review highlights the current knowledge of the differential actions of ghrelin-C8 and ghrelin-C10 from studies in the tilapia model. These findings suggest that the multiple forms of ghrelin may exhibit distinct yet complimentary actions directed toward maintaining overall energy balance in other vertebrates.

Keywords: ghrelin, GHS-R, tilapia, metabolism, appetite, homeostasis

\section{INTRODUCTION}

Ghrelin was first identified in rat stomach as an endogenous ligand for the growth hormone secretagogue receptor (GHS-R) (1). Ghrelin has since been identified in all vertebrate classes; fish (24), birds (5), amphibians (6), reptiles (7), mammals $(1,8)$, as well as sharks (9). All ghrelins identified thus far are uniquely and primarily acylated by octanoic or decanoic acid on the third amino acid from the $\mathrm{N}$-terminus $(10,11)$. However, a variety of other acyl-forms of ghrelins ( $n$-hexanoic and $n$-non-anoic acid) and unsaturated $n$-octanoic and $n$-decanoic isoforms of ghrelin have been identified $(5,12,13)$. The acyl modification is necessary for ghrelins biological action (10). Indeed, the first seven amino acid residues on the $\mathrm{N}$-terminus are highly conserved across vertebrates and are known as the "active core" $(11,14)$ suggesting an evolutionary conserved physiological role of ghrelin. Unlike tetrapod ghrelins, fish ghrelins possess an amide modification on the C-terminus (11). Ghrelin is predominately synthesized in the stomach and is also expressed in a variety of other tissues such as small and large intestine, pancreas, liver, hypothalamus, telencephalon, pituitary, gonads, kidneys, gills, adipose tissue, and many others $(14,15)$.

The biological actions of ghrelin are mediated by the GHS-R, which codes for two separate transcripts, GHS-R1a and GHSR1b (16). GHS-R1a is a seven transmembrane domain G-protein coupled receptor. This receptor is responsive to both synthetic growth hormone secretagogues and ghrelin in regulating several neuroendocrine, metabolic, and non-endocrine actions (15). The GHS-R1b transcript is shorter than the GHS-R1a isoform due to the intron not being spliced out thus disrupting the normal reading frame and resulting in a "non-functional" receptor with five transmembrane domains $(11,17)$. GHS-R1b has been suggested to act as a dominant-negative mutant. The formation of GHS-R1a/GHS-R1b heterodimer facilitates the translocation of GHS-R1a to the nucleus decreasing the constitutive signaling of GHS-R1a, thus inhibiting ghrelin's actions (18). Both isoforms are found in a variety of endocrine and non-endocrine tissues such as hypothalamus and a variety of other brain regions, pituitary, liver, lung, heart, muscle, kidney, and gonads (19). Two GHS-R isoforms have been identified in the black seabream (20). We have recently identified two GHS-R isoforms in the tilapia and determined their tissue distribution $(21,22)$.

The existence of ghrelin, GHS-R1a and GHS-R1b in fish suggests that the fundamental biological functions of ghrelin are conserved across vertebrate species $(19,20)$. In spite of the fact that all vertebrates possess multiple forms of ghrelin, nearly all of our understanding about ghrelin's biological actions has come from studies using the ghrelin-C8, thus leaving a huge gap in our understanding of ghrelin biology. This mini review focuses on the differential effects of ghrelin-C8 and ghrelin-C10 in tilapia. For more general information on the structure and function of ghrelin within vertebrates the reader is referred to the following review papers $(11,14,23,24)$.

\section{DIFFERENTIAL ROLES OF GHRELIN-C8 AND GHRELIN-C10 IN TILAPIA}

We have identified two forms of ghrelin in the Mozambique tilapia (Oreochromis mossambicus) stomach (4). They exhibit $100 \%$ amino acid identity with each other, the difference being the acyl modification ( $n$-octanoic or $n$-decanoic) on $\mathrm{Ser}^{3}$. The major form of tilapia ghrelin possesses an $n$-decanoic (ghrelinC10) modification (4). Multiple isoforms of ghrelin have been identified in other fish species, as observed in other vertebrates. Four isoforms of ghrelin have been identified in rainbow trout (2) and 11 isoforms of ghrelin have been identified in goldfish (25). In the chicken (5), ghrelin-C8 and ghrelin-C10 were isolated in similar amounts, whereas in goldfish (25), eel (3), bullfrog (26), and humans (27) ghrelin-C8 is the major form. Both acylated modifications are essential for receptor binding (28) and ghrelin transport across the blood-brain barrier (29). 
Since its original discovery as a potent growth hormone secretagogue, ghrelin has been shown to be involved in a variety of neuroendocrine, metabolic, and non-endocrine functions that include, but not limited to, orexigenic activity, cardiovascular, gastrointestinal, pancreatic, and lipogenic and glucogenic actions (15, $16,23,30)$. In spite of the fact that all vertebrates studied to date possess multiple forms of ghrelin, nearly all of the published work has focused on the biological functions of ghrelin-C8 and des-acyl ghrelin. Hosoda et al. (27) have demonstrated that ghrelin-C8 and ghrelin-C10 exhibit the same potency to increase $\left(\mathrm{Ca}^{2+}\right)$ levels in $\mathrm{CHO}$ cells expressing rat GHS-R $1 \mathrm{a}$ as well as stimulate $\mathrm{GH}$ release in rats. In goldfish des-acyl ghrelin was shown to attenuate the orexigenic actions of ghrelin-C8, but had no effect on food intake when administered alone (31). Notwithstanding, since des-acyl ghrelin has been shown to exhibit some biological functions [e.g., stimulate adipogenesis and cardioprotective actions $(32,33)]$, that the biological role - beyond stimulating GH release - of the other ghrelin forms have not been further investigated.

We have shown in tilapia that ghrelin-C8 and ghrelin-C10 appear to exhibit differential biological functions (30). GhrelinC10 was more potent than ghrelin-C8 in stimulating GH release from the tilapia pituitary, yet neither form altered pituitary $\mathrm{GH}$ mRNA expression levels (21). Both forms equally increased liver IGF-1 mRNA expression, but ghrelin-C8 was more potent than ghrelin-C10 in increasing liver growth hormone receptor mRNA expression in tilapia (21). Tilapia treated with ghrelin-C10 for 21 days (via osmotic pumps) exhibited a significant increase in food intake and body weight; ghrelin-C8 had no effect. The increase in body weight was likely a result of increased adiposity in liver and muscle tissue induced by ghrelin-C10 (34). Ghrelin-C8 has been shown to stimulate adiposity in rat bone marrow (33).

Brain neuropeptide Y (NPY) mRNA expression levels were significantly elevated 4 and $8 \mathrm{~h}$ following ghrelin-C10, not ghrelinC8, injection in tilapia (30). In goldfish, the orexigenic actions of ghrelin have been shown to be mediated by the NPY pathway (35), thus suggesting a similar mechanism of control in tilapia. In spite of the orexigenic actions of NPY in vertebrates (36), we have not observed an acute increase in food intake following either ghrelin-C8 or ghrelin-C10 treatment (unpublished observations). In rainbow trout, ghrelin-C8 treatment has been shown to have no effect on food intake (37), increase food intake (38), and inhibit food intake (37). In goldfish, two forms of octanoylated ghrelin (12- and 17-amino acid residues) stimulated food intake, whereas des-acylated ghrelin17 had no effect (25). Ghrelin-C8 treatment has routinely been shown to stimulate food intake in mammals $(24,39)$. However, studies using ghrelin $\left(\mathrm{ghrl}^{-1-}\right)$ knockout models $(40,41)$ suggest that ghrelin's role in stimulating food intake is secondary to its maintenance of metabolic energy balance (16, 42). The use of $\mathrm{ghrl}^{-1-}$ models provides a unique opportunity to investigate the differential roles of the multiple forms of ghrelin.

In tilapia, only ghrelin-C8 significantly elevated plasma glucose levels 4 and $8 \mathrm{~h}$ post intraperitoneal injection (30). In rainbow trout ghrelin-C8 stimulated glucokinase (GK) and pyruvate kinase activity, as well as increased the mRNA expression levels of glucose transporter-2 and GK in different regions of the brain, without altering plasma glucose levels (43). These data suggest that
ghrelin-C8, in tilapia and rainbow trout, may play a role in central glucose-sensing as well as in glucose metabolism in fish as observed in mammals (44). Des-acyl ghrelin had no effect on plasma glucose or insulin levels in healthy humans, but counteracted the actions of ghrelin-C8 on glucose and insulin levels (45). This indicates that des-acyl ghrelin possesses metabolic functions in mammals $(33,45)$. These data lend support to the hypothesis that the other acyl-forms of ghrelin may exhibit distinct functions from that of $n$-octanoylated ghrelin. Recently, we have observed that ghrelin-C8 reversed the negative effects of cortisol on the mRNA expression levels of the glucocorticoid receptor (GR) and GHS-R1a-LR in the hypothalamus of tilapia (Figures 1A,B, respectively). These data suggest that ghrelin-C8 may be playing a role in counteracting the negative effects of chronic stress and/or stress recovery in tilapia. We have previously observed differential regulation of the GHS-R mRNA isoforms in tilapia (46, $47)$. Further studies are needed to elucidate the biological significance of the different expression patterns of the GHS-Rs. Taken

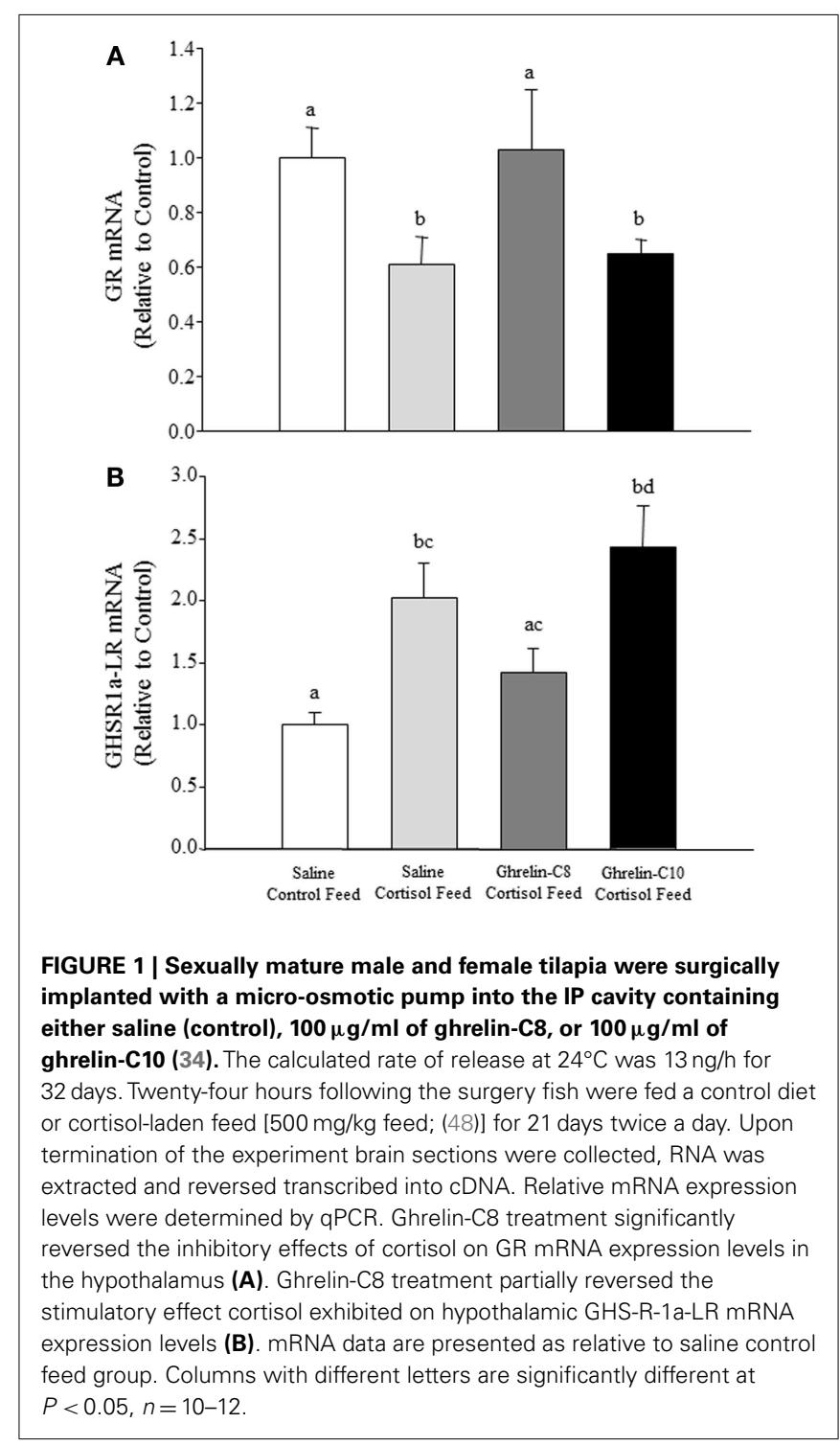


together, our data in tilapia clearly shows that ghrelin-C8 and ghrelin-C10 exhibit distinct, yet complimentary actions directed toward maintaining metabolic balance within the animal. Our laboratory is currently investigating the direct effects of ghrelinC8 and ghrelin-C10 on neuropeptide mRNA expression patterns using brain tissue culture methods and proteomic and metabolic approaches.

\section{CONCLUSION}

To date, all vertebrates produce multiple forms of ghrelin. There are reports that des-acyl ghrelin exhibits biological functions in mammals $(32,33)$ and that both ghrelin-C8 and ghrelin-C10 simulate $\mathrm{GH}$ release in rats (27), suggesting that the other

\section{REFERENCES}

1. Kojima M, Hosoda H, Date Y, Nakazato M, Matsuo H, Kangawa $\mathrm{K}$. Ghrelin is a growth-hormonereleasing acylated peptide from stomach. Nature (1999) 402:656-9. doi:10.1038/45230

2. Kaiya H, Kojima M, Hosoda H, Moriyama S, Takahashi A, Kawauchi H, et al. Peptide purification, complementary deoxyribonucleic acid (DNA) and genomic DNA cloning, and functional characterization of ghrelin in rainbow trout. Endocrinology (2003) 144:5215-26. doi:10.1210/en.2003-1085

3. Kaiya $H$, Kojima $M$, Hosoda $H$, Riley LG, Hirano T, Grau EG, et al. Amidated fish ghrelin: purification, cDNA cloning in the Japanese eel and its biological activity. $J$ Endocrinol (2003) 176:415-23. doi: 10.1677/joe.0.1760415

4. Kaiya H, Kojima M, Hosoda H, Riley LG, Hirano T, Grau EG, et al. Identification of tilapia ghrelin and its effects on growth hormone and prolactin release in the tilapia, Oreochromis mossambicus. Comp Biochem Physiol (2003) 135B:421-9.

5. Kaiya H, van der Geyten S, Kojima M, Hosoda H, Kitajima Y, Matsumoto $\mathrm{M}$, et al. Chicken ghrelin: purification, cDNA cloning, and biological activity. Endocrinology (2002) 143:3454-63. doi:10. 1210/en.2002-220255

6. Kaiya H, Sakata I, Yamamoto K, Koda A, Sakai T, Kangawa K, et al. Identification of immunoreactive plasma and stomach ghrelin, and expression of stomach ghrelin mRNA in the bullfrog, Rana catesbeiana. Gen Comp Endocrinol (2006) 148:236-44. doi:10.1016/j. ygcen.2006.03.008

7. Kaiya H, Sakata I, Kojima M, Hosoda H, Sakai T, Kangawa K. Structural determination and histochemical localization of ghrelin in the red-eared slider turtle, Trachemys scripta elegans. Gen Comp Endocrinol (2004) 138:50-7. doi:10. 1016/j.ygcen.2004.05.005

8. Ida T, Miyazato M, Naganobu K, Nakahara K, Sato M, Lin XZ, et al. Purification and characterization of feline ghrelin and its possible role. Domest Anim Endocrinol (2007) 32:93-105. doi:10.1016/j. domaniend.2006.01.002

9. Kawakoshi A, Kaiya H, Riley LG, Hirano T, Grau EG, Miyazato M, et al. Identification of a ghrelinlike peptide in two species of shark, Sphyrna lewini and Carcharhinus melanopterus. Gen Comp Endocrinol (2007) 151:259-68. doi:10.1016/j. ygcen.2006.10.012

10. Hosoda H, Kojima M, Matsuo H, Kangawa K. Ghrelin and des-acyl ghrelin: two major forms of rat ghrelin peptide in gastrointestinal tissue. Biochem Biophys Res Commun (2000) 279:909-13. doi:10. 1006/bbrc.2000.4039

11. Kaiya H, Miyazato M, Kangawa K, Peter RE, Unniappan S. Ghrelin: a multifunctional hormone in non-mammalian vertebrates. Comp Biochem Physiol A Mol Integr Physiol (2008) 149A:109-28. doi:10.1016/j. cbpa.2007.12.004 H, Sakata I, Oda S, et al. Identification of ghrelin in the house musk shrew (Suncus murinus): cDNA cloning, peptide purification and tissue distribution. Peptides (2009) 30:982-90. doi:10.1016/j.peptides. 2009.01.006

13. Nishi Y, Yoh J, Hiejima H, Kojima M. Structures and molecular forms of the ghrelin-family peptides. Peptides (2011) 32:2175-82. doi:10.1016/j. peptides.2011.07.024

14. Unniappan S, Peter RE. Structure, distribution and physiological functions of ghrelin in fish. Comp Biochem Physiol (2005) 140A:396-408.
12. Ishida Y, Sakahara S, Tsutsui C, Kaiya acyl-forms of ghrelin likely exhibit biological functions. In tilapia, both ghrelin-C8 and ghrelin-C10 exert distinct biological actions that appear to be directed toward maintenance of metabolic balance. It is not clear what is the mechanism underlying the different biological effects of ghrelin-C8 and ghrelin-C10. A possible hypothesis is that a third GHS-R-isoform that exhibits higher affinity toward ghrelin-C10 exists or that ghrelin-C10 binds non-specifically to a related receptor.

\section{ACKNOWLEDGMENTS}

This project was supported by Agriculture and Food Research Initiative Competitive Grant no. 2010-65206-20615 from the USDA National Institute of Food and Agriculture to Larry G. Riley.

15. Ghigo E, Broglio F, Arvat E, Maccario M, Papotti M, Muccioli G. Ghrelin: more than a natural GH secretagogue and/or an orexigenic factor. Clin Endocrino (2005) 62:1-17. doi:10.1111/j.13652265.2004.02160.x

16. Korbonits M, Goldstone AP, Gueorguiev M, Grossman AB. Ghrelin-a hormone with multiple functions. Front. Neuroendocrinol. (2004) 25:27-68. doi:10.1016/j.yfrne.2004.03.002

17. Davenport AP, Bonner TI, Foord SM, Harmar AJ, Neubig RR, Pin JP, et al. International Union of Pharmacology. LVI. Ghrelin receptor nomenclature, distribution, and function. Pharmacol Rev (2005) 57:541-6. doi:10.1124/pr.57.4.1

18. Leung PK, Chow KB, Lau PN, Chu $\mathrm{KM}$, Chan $\mathrm{CB}$, Cheng $\mathrm{CH}$, et al. The truncated ghrelin receptor polypeptide (GHS-R1b) acts as a dominant-negative mutant of the ghrelin receptor. Cell Signal (2007) 19:1011-22. doi:10.1016/j. cellsig.2006.11.011

19. van der Lely AJ, Tschop M, Heiman ML, Ghigo E. Biological, physiological, pathophysiological, and pharmacological aspects of ghrelin. Endocr Rev (2004) 25:426-57. doi: 10.1210/er.2002-0029

20. Chan C-B, Cheng CHK. Identification and functional characterization of two alternatively spliced growth hormone secretagogue receptor transcripts from the pituitary of black seabream, Acanthopagrus schlegeli. Mol Cell Endocrinol (2004) 214:81-95. doi: 10.1016/j.mce.2003.11.020

21. Fox BK, Riley LG, Kaiya $H$, Hirano T, Grau EG. Effects of homologous ghrelins on the growth hormone/insulinlike growth factor-I axis in the tilapia, Oreochromis mossambicus. Zoolog Sci (2007) 24:391-400. doi:10.2108/zsj.24.391
22. Kaiya H, Riley LG Jr, Hirano T, Grau EG, Miyazato M, Kangawa K. Identification and genomic sequence of ghrelin receptor (GHSR)-like receptor in the Mozambique tilapia, Oreochromis mossambicus. Zoolog Sci (2009) 26:330-7. doi:10. 2108/zsj.26.330

23. Kaiya H, Kangawa K, Miyazato M. What is the general action of ghrelin for vertebrates? - Comparisons of ghrelin's effects across vertebrates. Gen Comp Endocrinol (2013) 181:187-91. doi:10.1016/j. ygcen.2012.10.015

24. Kojima M, Kangawa K. Structure and function of ghrelin. In: Civand Problems in Cell Differentiation. Berlin: Springer Verlag (2008). p. 89-115.

25. Miura T, Maruyama K, Kaiya H, Miyazato M, Kangawa K, Uchiyama $\mathrm{M}$, et al. Purification and properties of ghrelin from the intestine of the goldfish, Carassius auratus. Peptides (2009) 30:758-65. doi:10. 1016/j.peptides.2008.12.016

26. Kaiya H, Kojima M, Hosoda $H$, Koda A, Yamamoto K, Kitajima Y, et al. Bullfrog ghrelin is modified by n-octanoic acid at its third threonine residue. J Biol Chem (2001) 276:40441-8. doi:10.1074/ jbc.M105212200

27. Hosoda H, Kojima M, Mizushima T, Shimizu S, Kangawa K. Structural divergence of human ghrelin: identification of multiple ghrelinderived molecules produced by post-translational processing. $\mathrm{J} \mathrm{Biol}$ Chem (2003) 278:64-70. doi:10. 1074/jbc.M205366200

28. Muccioli G, Tschop M, Papotti M, Deghenghi R, Heiman ML, Ghigo E. Neuroendocrine and peripheral activities of ghrelin: implications in metabolism and obesity. Eur J Pharmacol (2002) 440:235-54. doi:10.1016/S0014-2999(02) 01432-2 elli O, Zhou Q-Y, editors. Results 
29. Banks WA, Tschop M, Robinson SM, Heiman ML. Extent and direction of ghrelin transport across the bloodbrain barrier is determined by its unique primary structure. J Pharmacol Exp Ther (2002) 302:822-7. doi:10.1124/jpet.102.034827

30. Schwandt SE, Peddu SC, Riley LG. Differential roles for octanoylated and decanoylated ghrelins in regulating appetite and metabolism. Int J Pept (2010). doi:10.1155/2010/ 275804

31. Matsuda K, Miura T, Kaiya H, Maruyama K, Shimajura S-I, Uchiyama $M$, et al. Regulation of food intake by acyl and des-acyl ghrelins in the goldfish. Peptides (2006) 27:2321-5. doi:10.1016/j.peptides.2006.03.028

32. Li L, Zhang L-K, Pang Y-Z, Pan C-S, Qi Y-F, Chen L, et al. Cardioprotective effects of ghrelin and des-octanoyl ghrelin on myocardial injury induced by isoproterenol in rats. Acta Pharmacol $\operatorname{Sin}$ (2006) 27:527-35. doi:10.1111/ j.1745-7254.2006.00319.x

33. Thompson NM, Gill DA, Davies R, Loveridge N, Houston PA, Robinson IC, et al. Ghrelin and desoctanoyl ghrelin promote adipogenesis directly in vivo by a mechanism independent of the type 1a growth hormone secretagogue receptor. Endocrinology (2004) 145:234-42. doi:10.1210/en. 2003-0899

34. Riley LG, Fox BK, Kaiya H, Hirano T, Grau EG. Long-term treatment of ghrelin stimulates feeding, fat deposition, and alters the GH/IGFI axis in the tilapia, Oreochromis mossambicus. Gen Comp Endocrinol
(2005) 142:234-40. doi:10.1016/j. ygcen.2005.01.009

35. Miura T, Maruyama K, Shimajura SI, Kaiya H, Uchiyama M, Kangawa $K$, et al. Neuropeptide Y mediates ghrelin-induced feeding in the goldfish, Carassius auratus. Neurosci Lett (2006) 407:279-83. doi:10.1016/j. neulet.2006.08.071

36. Volkoff H, Canosa LF, Unniappan S, Cerda-Reverter JM, Bernier NJ, Kelly SP, et al. Neuropeptides and the control of food intake in fish. Gen Comp Endocrinol (2005) 142:3-19. doi:10.1016/j.ygcen.2004. 11.001

37. Jonsson E, Forsman A, Einarsdottir IE, Kaiya H, Ruohonen K, Bjornsson BT. Plasma ghrelin levels in rainbow trout in response to fasting, feeding and food composition, and effects of ghrelin on voluntary food intake. Comp Biochem Physiol A Mol Integr Physiol (2007) 147A:1116-24. doi:10.1016/j.cbpa.2007.03.024

38. Shepherd BS, Johnson JK, Silverstein JT, Parhar IS, Vijayan MM, McGuire A, et al. Endocrine and orexigenic actions of growth hormone secretagogues in rainbow trout (Oncorhynchus mykiss). Comp Biochem Physiol A Mol Integr Physiol (2007) 146:390-9. doi:10.1016/j. cbpa.2006.11.004

39. Hosoda H, Kojima M, Kangawa K. Biological, physiological, and pharamacological aspects of ghrelin. JPharm Sci (2006) 100:398-410. doi:10.1254/jphs.CRJ06002X

40. Sun Y, Butte NF, Garcia JM, Smith RG. Characterization of adult ghrelin and ghrelin receptor knockout mice under positive and negative energy balance. Endocrinology
(2008) 149:843-50. doi:10.1210/en. 2007-0271

41. Wortley KE, Anderson KD, Garcia K, Murray JD, Malinova L, Liu R, et al. Genetic deletion of ghrelin does not decrease food intake but influences metabolic fuel preference. Proc Natl Acad Sci U S A (2004) 101:8227-32. doi:10.1073/pnas.0402763101

42. Sato T, Kurokawa M, Nakashima $Y$, Ida T, Takahashi T, Fukue Y, et al. Ghrelin deficiency does not influence feeding performance. Regul Pept (2008) 145:7-11. doi:10.1016/ j.regpep.2007.09.010

43. Polakof S, Miguez JM, Soengas JL. Ghrelin effects on central glucosensing and energy homeostasis-related peptides in rainbow trout. Domest Anim Endocrinol (2011) 41:126-36 doi:10.1016/j.domaniend.2011.05. 006

44. Sangiao-Alvarellos S, Cordido F. Effect of ghrelin on glucose-insulin homeostasis: therapeutic implications. Int J Pept (2010) 2010:doi:10. 1155/2010/234709

45. Broglio F, Gottero C, Prodam F, Gauna C, Muccioli G, Papotti M, et al. Non-acylated ghrelin counteracts the metabolic but not the neuroendocrine response to acylated ghrelin in humans. J Clin Endocrino Metab (2004) 89:3062-5. doi:10. 1210/jc.2003-031964

46. Janzen WJ, Duncan CA, Riley LG. Cortisol treatment reduces ghrelin signaling and food intake in tilapia, Oreochromis mossambicus. Domest Anim Endocrinol (2012) 43:251-9. doi:10.1016/j.domaniend.2012.04. 003

47. Upton KR, Riley LG. Acute stress inhibits food intake and alters ghrelin signaling in the brain of tilapia (Oreochromis mossambicus). Domest Anim Endocrinol (2013) 44:157-64. doi:10.1016/j. domaniend.2012.10.001

48. Bernier NJ, Bedard N, Peter RE. Effects of cortisol on food intake, growth, and forebrain neuropeptide $\mathrm{Y}$ and corticotropin-releasing factor gene expression in goldfish. Gen Comp Endocrinol (2004) 135: 230-40. doi:10.1016/j.ygcen.2003. 09.016

Conflict of Interest Statement: The author declares that the research was conducted in the absence of any commercial or financial relationships that could be construed as a potential conflict of interest.

Received: 01 August 2013; accepted: 21 August 2013; published online: 03 September 2013.

Citation: Riley LG (2013) Different forms of ghrelin exhibit distinct biological roles in tilapia. Front. Endocrinol. 4:118. doi: 10.3389/fendo.2013.00118

This article was submitted to Experimental Endocrinology, a section of the journal Frontiers in Endocrinology.

Copyright $\left({ }^{\circ} 2013\right.$ Riley. This is an openaccess article distributed under the terms of the Creative Commons Attribution License (CC BY). The use, distribution or reproduction in other forums is permitted, provided the original author(s) or licensor are credited and that the original publication in this journal is cited, in accordance with accepted academic practice. No use, distribution or reproduction is permitted which does not comply with these terms. 